\title{
THE DOMINANCE OF INDIRECT TAXES IN ESTONIAN STATE BUDGET
}

\author{
Olev Raju \\ University of Tartu
}

\begin{abstract}
Recession has sharply erected the question of tax burden and the optimal proportion of different kinds of taxes among the incomes of the budget. Indirect taxes and consumption taxes, which proportion is different according to different methodologies, dominate in Estonian state budget. The buoyancy of a tax system based on taxes of that kind is especially weak during the recession.

Difficulties concerning the incomes of budget have arisen the necessity for lifting taxes, which is possible as the tax burden is low now. But a sharp question of the optimal level of taxes is going to be raised. A formula for indirect tax optimum according to Ramsey taxes and Slutski decomposition has been proposed in the article.
\end{abstract}

Keywords: Taxation, tax burden, Estonian state budget, Ramsey taxes, indirect tax optimum.

\section{The problem}

Everybody is familiar with the saying that death and taxes are the two most unpleasant as well as inescapable things. There are many goods that cannot be provided by the private sector but only by the state. Furthermore, with many goods provided by the private sector it is not possible to identify a consumer who would have to pay for them. It is the state that has to pay for these so-called public goods. According to Wagner's law the income elasticity of public expenditures is greater than 1, therefore the demand for state-financed services grows in proportion to the increase of income. That also means an increased demand for state budget revenues, mostly taxes. According to a popular opinion the state budget revenues should contain at least $90 \%$ taxes (loans not included).

Bigger state budget also means bigger taxes. Taxes in turn diminish the resources available to households and therefore welfare. So the question arises - which is bigger, the decrease in welfare of households and the state as a whole due to an increase of taxes, or the rise in welfare due to public goods and an increase in consumption? Naturally both these effects become evident through the behaviour of economic agents. Accordingly, with all taxes there is a question of their impact on the short- and long-term behaviour of economic agents.

In economic theory, this question can be approached from two viewpoints. First, it is possible to point out a set of principles, parameters and arguments, and construct models based on theoretical considerations, without taking into account particular numerical data. The other function of the theory is to provide a scientific set of analytical devices for the empirical data that would make giving practical 
suggestions possible. This part of the theory also needs to explain what kind of data from the millions of practical cases need to be gathered.

Not all of these interconnected problems can be discussed on these pages. We set out to consider two issues: first, to demonstrate the large proportion of indirect taxes in Estonian state budget, and second, to consider the problem of optimum in indirect taxing.

\section{Eliminating extranalities}

As a general rule, establishing or increasing taxes also raises prices. Accordingly, the reaction of households to taxes consists of the sum of two effects - income and substitution effect (the latter can be marginal, if the prices of all goods rise in proportion to the tax increase. But as the demand and supply elasticities of goods differ, this possibility is only theoretical and will therefore not be consider here). To achieve actual substitution effect the rise in prices needs to be compensated to the consumer. There are two possibilities for that - either to grant a specific amount of money to the consumer (household) based on the method introduced to the economic theory by Slutsky, or to try to compensate for the increase of prices to both the consumer and the supplier. If we choose the first option, Pareto effective situation is achievable (of course, in the absence of external effects and on the condition that indifference curve and isoquant are traditional) as a point of balance where the state incomes and expenditures for ensuring purchase power are even. The second option is of primarily theoretical interest as it would entail moving sums of money back and forth, and the final result would be marginal. We will not examine this option.

\section{Tax elasticity, buoyancy and incidence}

With any taxation system, three of its characteristics are of vital importance: elasticity, buoyancy and incidence. First of these shows the ability of a tax or of the system of all nationwide taxes to generate increased tax revenues in case of positive shifts in the object of taxation, primarily income or turnover. In practice, of course, tax elasticity depends on not only the type of tax, but also (if not primarily) on the structure of the system of collecting the particular tax. There are different approaches to buoyancy, but for the purposes of this study it is sufficient to regard it as a certain elasticity indicator in the situation where negative shifts are taking place in the object of taxation. The greater the buoyancy of a tax (and the whole system of taxation), the smaller the risk that in case of negative deviation in economy, primarily in the object of taxation, state income is significally reduced or the tax system even collapses.

The problem of the elasticity and buoyancy of tax systems was posed already in 1959 by R. A. Musgrave (Musgrave 1959). Since then, all taxes connected with consumership and sale (sale tax, excises, VAT etc) have been regarded as elastic. With income tax, opinions vary - it has been regarded as both elastic and anelastic. Customs tax and duties are universally regarded as anelastic (Goode et al. 1984). 
With buoyancy, the situation is more difficult. When it comes to analysis of buoyancy, authors either confine themselves to the analysis of elasticity in certain special cases (in the case of negative elasticity coefficient) or essentially forgot it. The reason for that is simple - during the past few decades there has been no opportunity to study national tax systems in a situation of clear economic depcession. The last bigger and more widespread depression took place in 1974-75 and even that was due to external factors (negative supply shock caused by oil prices), and therefore the analysis of the data from that period does not always produce "pure" results. Of course, it is not advisable to confine oneself to mere theoretical approaches or make conclusions based on 50-year-old data. In that sense the current depcession in Estonia and elsewhere is an interesting base material for future research. However, these analyses can be properly made only in a few years' time.

The questions of tax incidence have received more attention. The spreading on tax burden between demandant and supplier, but also between different social strata of varying income, is the key question of not only taxation, but of all macroeconomics and economic policy. By how much does the income of a certain social stratum decrease in real life and how much does the demand drop as a consequence? If the supplier becomes the tax bearer, then by how much do the prices rise? How much does that in turn reduce demand? It is a wide-spread view that indirect taxes, which dominate in developing countries and make up a particularly large percentage in Estonia, are regressive towards income. Unfortunately the latest in-depth statistical studies in that field date back to more than 30 years ago, when the tax systems of newly independent developing countries were actively researched. As those countries quickly changed the structure of their taxes, there are almost no studies about countries with a tax system analogous to that of Estonia today. Even of Eastern European countries only Latvia has a tax structure similar to Estonia.

\section{Estonian taxation structure}

In the initial stage of its tranition period, Estonia (like most other Eastern European countries) was in a unique position - it essentially lacked a taxation system, a vital instrument of economic policy, which now needed to be constructed. In a perfect world, that would have meant building a system based on contemporary economic theory. Unfortunately Eastern European countries lacked pertinent knowledge, both in regard to taxation theory and the economic situation (an accurate description of the development phase and the processes).

Estonian budget and tax systems were largely developed in 1993-1994 and many of their key features have remained unchanged. The only important change has been the abolition of corporate income tax in 2000 (that experiment will not be analyzed here). Estonian tax system has been praised as unique, simple and conductive to economy, and criticized as primitive, helpless, not boosting the economy and generating social discrepancies. It is an issue of difference of values (as well as political competition) that have a particularly acute expression in this context. When 
it comes to taxes, vastly different viewpoints are presented not only in scientific publications but also in textbooks (Truu 1987; Stiglitz 1995).

So what characterizes the Estonian tax system? Its characteristic features are a relatively low tax burden, simplicity bordering on primitiveness (which has significantly reduced the possibilities of using taxes as a control device of economy), a very high percentage of indirect and consumption taxes.

The tax burden in Estonia has been 33.7-35.1\% since Estonia joined the EU (Estonian Ministry of Finance website; the data are slightly different in various parts of the website). That is lower than the EU average (41-42\%). However, these numbers are not comparable. Estonian state budget includes social benefits tax, which has for many years been the greatest source of income for the state budget (Table 1). In most EU member states such a tax does not exist or is slight. When that is taken into account, the tax burden in Estonia appears to be about 25-26\%.

Table 1. Income from taxes in Estonian state budget 2005-2008 (in milliards of kroons)

\begin{tabular}{|l|r|r|r|r|}
\hline & \multicolumn{1}{|c|}{2005} & \multicolumn{1}{c|}{2006} & 2007 & $\begin{array}{c}2008 \\
\text { (provisional) }\end{array}$ \\
\hline Total taxes & 53831 & 55208 & 67718 & 70396 \\
\hline Personal income tax & 10911 & 3846 & 4786 & 4328 \\
\hline Corporate income tax & 2365 & 3123 & 4083 & 4166 \\
\hline VAT & 14021 & 18645 & 22304 & 20548 \\
\hline Excises & 6424 & 7030 & 8195 & 8971 \\
\hline excise on tobacco & 1205 & 1208 & 1529 & 2519 \\
\hline excise on alcohol & 1838 & 2089 & 2314 & 2434 \\
\hline excise on fuel & 3363 & 3728 & 4353 & 4697 \\
\hline excise on packaging & $\ldots$ & 3 & $\ldots$ & 1 \\
\hline Gambling tax & 292 & 354 & 467 & 484 \\
\hline Customs tax & 347 & 401 & 549 & 508 \\
\hline Social benefits tax & 18392 & 21764 & 27268 & 31299 \\
\hline Other taxes & 1079 & 45 & 66 & 92 \\
\hline
\end{tabular}

Source: Author's calculations based on Estonian Ministry of Finance website.

The economic crisis has brought attention to the issue of tax structure. Table 1 presents taxes in Estonian state budget from 2005, i.e after Estonia joined the EU. It is difficult to assess what is the percentage of indirect taxes in Estonian state budget. Indirect taxes clearly include VAT, excises and the customs tax. However, also the gambling tax has some features characteristic to indirect taxes, as it is not imposed on the revenues from economic activities but rather as a preventive lump-sum tax, i.e before launching the slot machine etc. The tax sum is transfered by the manager of the gambling business in some way (e.g by raising drink prices) to the actual bearer - the gambler, i.e consumer. Accordingly this tax also has the incidence 
characteristic of indirect taxes and therefore it is more accurate to regard it as an indirect tax (at least when it is established in such a way as in Estonia).

As far as we know, there is no other country that has social benefits tax in the form that it exists in Estonia. The tax is paid by the employer, but it is calculated based on the amount of money paid to the employee. That tax is meant only for pensions and healthcare, i.e it functions largely as retirement and health insurance. Clearly, the defining criterium here is whether the emplyee's salary would increase by the amount that makes up the social benefits tax if that tax was abolished. If yes, the social benefits tax has enough characteristic features to regard it as an indirect tax; if not, the features of direct taxes probably prevail (the social benefits tax is the employer's expenditure). As this question is impossible to answer properly, authors classify it arbitrarily, depending on their views, as either a direct or indirect tax. Eurostat has taken a "diplomatic" position and classifies that Estonian social tax as a labour tax, regarding it therefore as primarily a resource tax (Eurostat. Taxation), but that is not entirely accurate as the income from social benefits tax is allocated for certain social expenditures.

It is probably reasonable to bring out the percentage of indirect taxes in different versions, with social benefits tax included and not. In the first case, the percentage of indirect taxes has made up 75.3-87.8\% of state budget revenues ever since Estonia joined the EU; in the latter case the percentage has been $41.1-53.6 \%$. If we take the first approach, we arrive at what is clearly the biggest percentage of indirect taxes among EU member states; even with the second approach the result is well above EU average.

When trying to determine the percentage of consumption taxes in Estonian state budget, we likewise have to face the question of how to classify some taxes that are different from those in other countries. Again we are talking mainly about social benefits tax. In the form that it exists in Estonia, it has been regarded as a tax on using one of the goods - labour - and hence as a resource tax. That, however, raises the question of whether it is a consumption tax. It is not the purpose of this study to discuss whether the multifunctional tax established during the transition period when there was no economicic-theoretical knowledge available belongs to this or that category. Therefore - although the author does not share the opinion that the social benefits tax as it exists in Estonia is a consumption tax - also the percentage of consumption taxes has been given in two versions in Table 2 - with social benefits tax included and not. It is clear that consumption taxes include VAT and excises. But does the customs tax on alcohol, furniture, meat etc count as a consumption tax? More likely yes - without consumption there is no tax. It is also certain that customs increase the prices and limit consumption - nobody will import if there is no demand. Gambling tax, as it exists in Estonia, should probably be classified as a consumption tax as well. Factor payments for the local governments can also be counted in, but these are not reflected in the state budget and will therefore not be considered here. 
Table 2. Indirect taxes in Estonian state budget 2005-2008.

\begin{tabular}{|l|r|r|r|r|}
\hline & \multicolumn{1}{|c|}{2005} & \multicolumn{1}{c|}{2006} & \multicolumn{1}{c|}{2007} & \multicolumn{1}{c|}{$\begin{array}{c}\text { 2008 } \\
\text { (provisional) }\end{array}$} \\
\hline Total taxes & 53831 & 55208 & 67718 & 70396 \\
\hline $\begin{array}{l}\text { Indirect taxes (social benefits tax } \\
\text { included) }\end{array}$ & 40505 & 48217 & 58816 & 61856 \\
\hline $\begin{array}{l}\text { Percentage of indirect taxes } \\
(\%, \text { social benefits tax included) }\end{array}$ & 75.3 & 87.3 & 86.9 & 87.8 \\
\hline $\begin{array}{l}\text { Indirect taxes (social benefits tax not } \\
\text { included) }\end{array}$ & 22113 & 29572 & 31548 & 30557 \\
\hline $\begin{array}{l}\text { Percentage of indirect taxes } \\
(\%, \text { social benefits tax not included) }\end{array}$ & 41.1 & 53.6 & 46.6 & 43.4 \\
\hline $\begin{array}{l}\text { Consumption taxes, social benefits tax } \\
\text { included }\end{array}$ & 40505 & 48217 & 58816 & 61856 \\
\hline $\begin{array}{l}\text { Percentage of consumption taxes } \\
(\%, \text { social benefits tax included) }\end{array}$ & 75.3 & 87.3 & 86.9 & 87.8 \\
\hline $\begin{array}{l}\text { Consumption taxes, social benefits tax } \\
\text { not included }\end{array}$ & 22113 & 29572 & 31548 & 30557 \\
\hline $\begin{array}{l}\text { Percentage of consumption taxes } \\
(\%, \text { social benefits tax not included) }\end{array}$ & 41.1 & 53.6 & 46.6 & 43.4 \\
\hline
\end{tabular}

Note. Of "other taxes" 50\% have been taken to be indirect.

Source: Author's calculations based on the data from Table 1.

As seen from the figures presented in Table 2, a peculiar situation has taken shape in Estonia - if we take the above considerations (which are, admittedly, debatable) into account when classifying taxes, the percentage and amount of indirect and consumption taxes in the state budget coincide. Regardless of how exactly we classify these taxes, we have to acknowledge that their proportion in the state budget is big. The figures in Table 1 and 2 also demonstrate the marginal role of environment taxes (which make up part of the "other taxes") in Estonian state budget.

It only takes basic calculation of percentage to demonstrate the growing dominance of social benefits tax in Estonian state budget - from $34.2 \%$ in 2004 to $44.4 \%$ in 2008. The economic crisis that started in 2008 will, however, in connection to the substantial rise in unemployment freeze the salaries to be paid in 2009. That in turn will lead to a drop in the income from social benefits tax. The halting of an increase in household incomes - or even their decrease - will, considering the big loan burden of households, lead to a decrease of VAT and excises.

That has already put enormous pressure on the 2009 state budget - it is clear that the absolute sum will be significantly smaller than in 2008. The revenues of a budget based on consumption taxes will probably have good elasticity during periods when incomes and consumption are quickly rising, but the buoyancy of such a system is weak. All prognoses, without exception, predict a substantial decrease in the rate of inflation (which has been high, ca 10\% during the past few years) or even a decrease 
in prices (Estonian Ministry of Finance ...). Given the $44.4 \%$ social benefits tax and $29.2 \%$ VAT in the 2008 state budget, that adds further pressure on the 2009 budget.

The question of increasing Estonian tax burden has become relevant. That brings forward the issue of optimal tax rates.

\section{Optimal tax rates}

As mentioned earlier, the decrease in state budget revenues has raised the question of a possible increase of tax burden in Estonia, and that already in 2009. Next we will try to construct a model to determine the optimum of the dominant indirect taxes.

In an attempt to maintain comprehensiveness, we will base our model on two common views on model-construction in taxation theory. First, the state revenues from taxes come as lump-sum taxes straight from households, and second, any transaction between the consumer and the supplier increases state revenues. There are no external forces, the indifference curve and isoquant are standard. In the absence of any other taxes such premise leads to Pareto optimum in the point where the increase in state revenues and the purchasing power redistribution curve meets with the lump-sum taxes curve. Adding any other taxes directs us away from that point. Essentially we are trying to find a solution that would bring about an increase in state revenues by increasing consumption taxes, while reducing the welfare of households as little as possible. If we expect taxes to be used for an increase in social welfare, we can claim that when the left side of equation (1) exceeds the right side, the total social welfare has increased.

To put it in the form of an equation: we are trying to choose the tax vector $t$ in such a way as to maximize social welfare $\mathrm{V}(\mathrm{q})$. If we designate the total revenue of subjects from indirect taxes with $\mathrm{R}(\mathrm{t})$, we arrive at:

$$
\mathrm{R}(\mathrm{t})=\mathrm{t} \cdot \mathrm{X}(\mathrm{q}) \geq \vec{R}
$$

where $X(q)$ is the vector of aggregated demand and

$\vec{R}$ is the required tax revenue.

With taxes imposed, a quantity $q$ is supplied for price $t$, but the consumer pays the price $(p+t)$. We designate the household welfare corresponding to quantity $q$ with $\mathrm{v}(\mathrm{q})$ and the household demand with $\mathrm{x}(\mathrm{q})$ and arrive at equation (1). Again, $\mathrm{V}(\mathrm{q})$ is the rise of social welfare caused by an increase in taxes.

The problem posed is easily solved if we use Ramsey's rule of optimal taxes and Lagrange's widespread method of determining maximum. We maximize $\mathrm{V}+\lambda \mathrm{R}$, where $\lambda$ is the Lagrange multiplier, which in this case does not indicate the marginal utility of some particular good supplied by the private sector, but of the social welfare arising from the increase in state revenues. 
We can write:

$$
\frac{\partial V}{\partial t_{i}}+\lambda \frac{\partial R}{\partial t_{i}}=0 \text {. }
$$

If we make the substitution

$$
\partial V / \partial t_{i}=-\sum_{h} \beta^{h} x_{i}^{h} \quad \text { and } \quad \partial R / \partial t_{i}=X_{i}+t \cdot \partial X / \partial t_{i}
$$

and use Slutsky's compensated demand curve of demand derivative, we get:

$$
\begin{aligned}
& \frac{\sum_{k} t_{k} \sum_{h} s_{i k}^{h}}{X_{i}}=-\sigma_{i} \\
& \sigma_{i}=1-\sum_{h} \frac{x_{i}^{h}}{X_{i}} \frac{b^{h}}{\bar{b}}
\end{aligned}
$$

$\mathrm{S}_{\mathrm{ik}}{ }^{\mathrm{h}}$ is the derivative of Slutsky's compensated demand curve on household $\mathrm{h}$ (the utility level preceding the tax increase has been maintained) and $\sigma_{i}$ is negative because there is a covariance, $b^{\mathrm{h}}$, of the social marginal utility of the net income of household $\mathrm{h}$ (where the "net" means there is an adjusment to the social marginal utility, $\beta^{\mathrm{h}}$, for the marginal propensity to spend on taxes out of extra income, and $b$ is the average of $\left.b^{h}\right)$ and the consumption of good $i$ by houshold $h,\left(x_{i}^{h}\right)$. Thus, $\sigma_{i}$ is higher the more good is consumed by those who have a low social marginal utility of income.

As the above equations (1) and (2) take into account the most important aspects of the interconnection of taxes and social welfare, it can be successfully used to describe the social aspect of the efficiency of indirect taxes. However, these equations as well as those suggested earlier (Ahmed; Stern, 1989) are practicable only on the condition that we succeed in mathematically describing the function of the social welfare of households, from which we can then find the derivative. As a rule, the task of describing the function of the welfare of households is often difficult to solve with adequate accuracy, i.e the same kind of problems arise as in the case of using Hicks's method to subtract the substitution and income effect.

\section{Conclusion}

The following can be concluded from the above:

1. Determining the percentage of indirect and consumption taxes in the whole tax burden is complicated as there is no generally accepted method for it. Also, several of the taxes used in Estonia possess features characteristic of both direct and indirect taxes. Furthermore, it is not clear what we should consider a consumption tax - only 
those taxes that affect household consumption, or also corporate ones in case the tax is imposed on final consumption.

2. Whichever approach we take to defining indirect and direct taxing, it is clear that indirect taxes prevail in the income of the Estonian state budget. The social benefits tax makes up a particularly big - and growing - proportion. Different approaches lead to the same conclusion: the percentage of consumption and indirect taxes in the state budget is equal, i.e indirect taxes have been imposed on consumption.

3. The structure of the revenues of the Estonian state budget differs considerably from that of other EU member states. The percentage of environment taxes is negligible, while the peculiarly structured social benefits tax, which constitutes the greatest and increasing source of revenue of the state budget, is difficult to classify as either a direct, indirect or labour tax. Due to the huge proportion of consumption taxes the buoyancy of Estonian tax system is weak. The provisional conclusions of 2008 demonstrate clearly that during periods of economic recession the state budget is very vulnerable.

4. The shortfall of income to the state budget in 2008 and especially at the beginning of 2009 has forced the government to make cutbacks up to $10 \%$ and has acutely raised the issue of increasing the tax burden. As the tax burden in Estonia is substantially lower than the EU average, it is possible. However, that raises the question of the optimal tax burden. Based on Slutsky's principle of compensated demand curve and Ramsey's optimal tax theory we can take the optimal level of indirect taxes (which are dominant in Estonia) to be the point where the household welfare reduction curve and the social welfare increase curve intersect.

\section{References}

1. Ahmad, E., Stern, N. (1989). Taxation for developing countries. Handbooks in economics. V. II. pp. 1005-1092.

2. Eurostat. Taxation, http://epp.eurostat.ec.europa.eu/portal/page?- pageid/.

3. Goode, R. (1984). Government finance in developing countries. Washington, DC.

4. Musgrave, R. A. (1959). The theory of public finance. New York.

5. Newberry, D. M., Stern, N. (2007). The theory of taxation for developing countries. Oxford.

6. Stiglitz, J. E. (1995). Ühiskondliku sektori ökonoomika. Tallinn.

7. Truu, M. L., Contogiannis, E. (1987). Macroeconomics. Cape Town.

8. Estonian Ministry of Finance website, http://www.fin.ee/. 